Please do not remove this page

RMIT

UNIVERSITY

\title{
Accounting for future generations: Intergenerational equity in Australia
}

Bessant, Judith; Emslie, Michael; Watts, Robert

https://researchrepository.rmit.edu.au/esploro/outputs/9921857751001341/filesAndLinks?institution=61RMIT_INST\&index=null

Bessant, J., Emslie, M., \& Watts, R. (2011). Accounting for future generations: Intergenerational equity in Australia. Australian Journal of Public Adminstration, 70(2), 143-155.

https://doi.org/10.1111/j.1467-8500.2011.00723.x

Document Version: Published Version

Published Version: https://doi.org/10.1111/j.1467-8500.2011.00723.x

Repository homepage: https://researchrepository.rmit.edu.au

(c) 2011 The Authors (c) 2011 Authors and National Council of the Institute of Public Administration Australia

Downloaded On 2023/04/26 20:09:48 +1000

Please do not remove this page 
Thank you for downloading this document from the RMIT Research Repository.

The RMIT Research Repository is an open access database showcasing the research outputs of RMIT University researchers.

RMIT Research Repository: http://researchbank.rmit.edu.au/

\section{Citation:}

Bessant, J, Emslie, M and Watts, R 2011, 'Accounting for future generations: Intergenerational equity in Australia', Australian Journal of Public Adminstration, vol. 70, no. 2, pp. 143-155.

See this record in the RMIT Research Repository at:

https://researchbank.rmit.edu.au/view/rmit:23377

Version: Published Version

\section{Copyright Statement:}

(C) 2011 The Authors (c) 2011 Authors and National Council of the Institute of Public Administration Australia

\section{Link to Published Version:}

http://dx.doi.org/10.1111/j.1467-8500.2011.00723.x 


\title{
Accounting for Future Generations: Intergenerational Equity in Australia ${ }^{1}$
}

\author{
Judith C. Bessant, Michael Emslie and Rob Watts \\ RMIT University
}

\begin{abstract}
Australian governments have published three intergenerational reports since 2002. In line with a general international trend these reports pointed to a problem said to arise from an ageing population which exposes Australia to the risk of a future major fiscal crisis. In this article we argue that by failing to use a generational accounting framework, the reports privilege the elderly at the expense of young people. Added to this, they fail to engage any discussion of intergenerational equity defined as distributive fairness and justice. In this article we explore the value of various approaches to intergenerational justice, focusing on the Principle of Intergenerational Neutrality derived from Rawls' theory of justice. We argue that this does not work as well from a policy point of view as Sen's freedom-as-capabilities approach. We conclude that linking Sen's approach to justice to a generational accounting will enable governments to address future issues of equity.
\end{abstract}

Keywords: intergenerational equity, age, youth, generational accounting, justice, fiscal accountability, policy

Something is profoundly wrong with the way we live today ... We no longer ask of a judicial ruling or a legislative act: is it good? Is it fair? Is it just? Is it right? Will it help bring about a better society or a better world? These used to be the political questions, even if they invited no easy answers. We must learn once again to pose them (Judt 2010:17).

Since the 1990s most Western nation-states have acknowledged that they are undergoing a major demographic transformation involving a significant increase in the number and proportion of elderly people. In consequence both national governments and entities like the Organisation for Economic Cooperation and Development, the International Monetary Fund and the European Union have begun exploring the policy implications of this (Heller, Hemming and Kohnert 1986; Liebfritz et al. 1995; Hauner, Leigh and Skaarup 2007). Most of this work has been framed by a preoccupation with fiscal sustainability (Larch and Noguei-Martins 2006; Ballassone et al. 2009;
Gokhale 2009). ${ }^{2}$ Relying on forecasts of fertility trends, economic growth and various assumptions about debit-deficit dynamics, many governments have concluded that they face a looming crisis of fiscal sustainability. ${ }^{3}$ As Ballassone et al. (2009:8) suggest, there is now a consensus that: '.. overall projected ageing populations [are] projected to lead to increases in public spending in most member states by 2050 on the basis of current policies'. Given that the policy problem has been defined as long term fiscal sustainability, the conclusion is drawn that future generations face an increasing financial burden (Bonin 2001). ${ }^{4}$

Australian governments have demonstrated considerable interest in this matter. Following the Charter of Budget Honesty Act 1998 introduced by the Coalition Howard government (1996-2007), Australia has published three intergenerational reports (Commonwealth of Australia 2002, 2007, 2010). These reports are designed to assess 'the long-term sustainability of current policies' over a 40 year 
projection, taking account of 'the financial implications of demographic change' (Commonwealth of Australia 2002:i). Like the European exercises, the first report of 2002 produced by the Howard government framed the policy problem in terms of an impending fiscal problem. It argued Australia would see a tripling in the numbers of people over 85 years of age while the proportion of those aged 15-64 would fall over the following 40 years (Commonwealth of Australia 2002). The first report (Commonwealth of Australia 2002) also predicted that Commonwealth spending would begin to exceed revenue by 2018 resulting in a budget deficit of $\$ 87$ billion by 2041-42 (equivalent to $5 \%$ of projected Gross Domestic Product (GDP) in 2041-42). If the 2010 Intergenerational Report is any guide, Australia's Labor government has embraced this framing. The intergenerational report of 2010, for example, forecast an increase in the proportion of elderly people, a decline in labor force participation and reduced rates of economic growth, arguing that future governments would face mounting costs associated with increasing demands on the health system, aged care and aged pensions (Commonwealth of Australia 2010: 3-5).

As Schon (1984), Bessant (2008:361-373) and Bacchi (2009) have argued, the way solutions to a problem are generated depend on how the policy problems are represented. In that vein Doughney and King (2006:24) argued that the 2002 Intergenerational Report was driven by a preoccupation with 'looking for ways to increase the size of the economy so we all have higher incomes' while suggesting that a 'key way to improve economic growth is through increases in labour force participation and productivity' (cf. Harvey 2005; Prasad 2006). Gee and Gutman (2000) have been critical of the 'demographic alarmism' at work in the research on intergenerational equity.

As Robinson and Watts-Roy (1999) describe it, public policy exercises like the Australian intergenerational reports are central to the 'generational equity debate'. They say that this:

... is the most recent incarnation of a question that has been with us since the dawn of recorded history, the question of what share of family and/or community resources should be consumed by the elderly (Robinson and Watts-Roy 1999:4).

What should we think about this way of framing the policy problem? Are we justified as imply treating the intergenerational equity problem as a problem focused on the elderly? (Robinson and Watts-Roy 1999). Secondly, given that Europeans have raised important questions about the principles of 'intergenerational ethics' and 'intergenerational justice', how well have economists the group most involved in producing the intergenerational reports addressed the ethical dimensions of intergenerational equity? (see Solum 2001 and Tremmel 2009). How might Australian governments better engage the ethical problems of intergenerational equity?

Mindful of the larger body of international research and policy discussion, we focus on the things said and the things left unsaid in Australia's intergenerational reports published in Australia in consequence of the passage of the Charter of Budget Honesty Act 1998. Though there are some idiosyncratic features involved in the three Australian intergenerational reports, we argue that there are enough features shared in common with equivalent international exericises to give this article some wider application while being of interest to local policy and research communities.

We will argue there are grounds for concern. While there are a number of technical problems in the reports worth identifying, our primary concern is the absence of an interest in the needs and perspectives of young people who are alive now or of those yet to be born. Secondly, we agree with Thompson (2003, 2004) when she says that the intergenerational reports avoid the "philosophical questions that engage ethical concerns about distributive fairness and justice and our moral obligations to future generations'. Like Parfit (1984), Partridge (2008: 4-7), Page (2008:8-14), Tremmel (2009) and Thompson (2009), we argue it is both possible and desirable to make just provision for people not yet born. That the intergenerational reports have failed to consider the question of justice is a serious deficit in the political and 
policy deliberative processes in the Australian polity. For that reason we briefly explore some of the possible approaches to justice including Sunstein's (2007) Principle of Generational Neutrality that might inform an intergenerational justice framework. Finally we draw on Sen's $(2002,2009)$ recent policy-focused arguments for adopting a freedom-as-capability framework that we think might inform a more adequate generational accounting framework. We begin by recapping what the intergenerational reports say.

\section{Australia's Intergenerational Reports 2002-10: Predicting Fiscal Crisis}

There is general agreement in the three intergenerational reports about the problem Australia faces - though the emphasis on particular themes shifts slightly from report to report. Each points to a major demographic transformation in Australia. This is described, for example, as the expectation that the 'number of people aged 55 and over will grow faster than the number aged under 55' (Commonwealth of Australia 2002:5). The 2010 report suggested that while the number of children would grow by $45 \%$ and the number of prime age working people would increase by $44 \%$, 'this will occur at the same time as the number of older people (65 to 84 years) more than doubles and the number of very old (85 and over) more than quadruples' (Commonwealth of Australia 2010:5). Each report has argued there will be a dramatic rise in the 'dependency ratio' and emphasises that as aged and child dependency increases there will be fewer people of prime work age (15-64) in the workforce. According to the last report: in ' 1970 there were 7.5 people of working age to support every person aged 65 and over', 'by 2050 this number is projected to decline to 2.7 people of working age to support every person aged 65 and over' (Commonwealth of Australia 2010:5-6).

Each report asserts that the demographic shift has significant implications for the revenue stream governments rely on to fund basic social services. Each report says that the central problem will be the increased costs of support- ing the burgeoning proportion of older people. This will lead to a looming fiscal crisis as total government spending rises from $22.4 \%$ of GDP (in 2015-16) to $27.1 \%$ of GDP by 2049 50 with a predicted gap between revenue and expenditure equivalent to $2 \frac{3}{4} \%$ of GDP in 2050 (Commonwealth of Australia 2010:xi).

The explanation offered points to cost pressures associated with an ageing population and especially increased health costs. The 2010 report states that a quarter of total government spending was on health, aged-pensions and aged care in 2009-10. This is projected to rise to half by 2050 (Commonwealth of Australia 2010). Moreover, coupled with declining rates in the labour force and decreased productivity and falling GDP, the capacity of the taxation system to generate the revenues to fund these demands is expected to weaken. Each report forecasts a 'fiscal gap'. The third intergenerational report suggested that if there was no action, the budget would be in deficit (or $3 \frac{3}{4} \%$ of GDP) and net debt would grow to around $20 \%$ of GDP by 2050 (Commonwealth of Australia 2010).

How should we think about these reports? We might point to the problem involved whenever social scientists make predictions. Philosophers and social scientists from Mayo (1949), Merton (1948), Popper (1959), Giddens (1990) and Soros (2008) have argued that predictions should generally not be taken too seriously. Their point was summed up by J. K. Galbraith (1975:13) when he suggested that the only function of 'economic forecasting is to make astrology look respectable'. Alternately we might draw attention to the reliance of the reports on problematic assumptions. Kinnear (2001) or Ablett (1996, 1998), for example, have challenged the premise that older people are a social and economic burden. However our preference here is to point to some large problems that relate to the way the problem is represented as a problem of 'fiscal sustainability' when the larger and unstated problem is the question of intergenerational equity. At stake is the important question of justice. Both our intuitive conceptions of justice and the most sophisticated theories of justice have their origins in the recognition that a certain state of 
affairs is not fair. As Ricoeur (2000:viii) says, 'Was not our entry into the region of lawfulness marked by the cry, 'that's not fair'.

\section{Missing in Action: Intergenerational Equity}

Thompson $(2003: 3-4,2004)$ argued that the 2002 report confronted one basic question that was not addressed: what is wrong with future generations facing a greater tax burden (fiscal inequity) or a greater level of public debt than we do? As she observes, 'These questions are not fiscal nor technical economic ones, but philosophical questions which engage ethical concerns about distributive fairness'. That problem characterises the other two reports. Other commentators have also noticed this absence. Tapper (2002) noted that the first intergenerational report offered only a slender framework at best for addressing issues of fairness across the generations. As Tapper (2002) noted the 'welfare state' has never attempted to address or measure, or indeed aim at, producing intergenerational equity. Coombs and Dollery (2004b:460) concur, observing that: 'A surprising feature of this nascent literature is the fact that it has focused heavily on long-term fiscal sustainability but overlooked the importance of intergenerational equity' (see also Miller and Siggins 2003).

Yet the situation is worse than these commentaries have suggested. Firstly given that the focus is ostensibly on intergenerational matters, it is odd that the perspectives and interests of one generation, namely young people have simply been omitted from the Australian policy discussion to date. This is quite an omission given the current size of the age cohort for example aged 12-25, to say nothing of the size of this age cohort in say 2040 or 2050 . Little attention has been given to the current socioeconomic issues that young people face that cause them hardship and suffering. Descriptions of the looming 'demographic problem' have simply not addressed the needs or interests of current cohorts of young people, except to observe in passing that 'they' are not going to be able to fund the costs of an ageing population. Perhaps for that reason and running hard against the trend in Australia to avoid generational accounting, Ablett (1996:91) argued for factoring in young people to address a 'real cause for concern'. Macfarlane (2003:19) too has warned about the implications of this omission:

The young may resent the tax burden imposed on them to pay for pension and health expenditures on the old. This will, particularly be the case if they see the old as owning most of the community's assets.

In short while the intergenerational reports have had a lot to say about fiscal sustainability, they have said nothing about intergenerational equity. Each of the reports ignores existing intergenerational inequities as well as future likely inequities. This owes much to the fact the fact that the Australian reports have not emulated the kind of generational accounting which is the 'normal' framework in most international intergenerational policy research. Australia decided not to use the generational accounting approach pioneered by Auerbach et al. (1991, 1994, 2004; see also Raffelhuschen 1999:168). The three intergenerational reports have nowhere analysed public policies in agecohort or generational terms. This absence has made it certain that this issue could not be addressed in Australia. In spite of the fact that Australia has produced three intergenerational reports, the question of intergenerational equity still remains to be addressed.

Our second large point is that there is no discussion of the possible principles for acknowledging or addressing intergenerational equity in ways which explicitly address the interests of those who are yet to be born, but whose existence is being implicitly factored in each of the reports. In short, each reports fails to ground their projection of concerns in a conceptually rigorous idea of intergenerational equity grounded in a defensible conception of justice.

\section{Justice and Intergenerational Equity}

Each intergenerational report implies that maintaining Australia's current low tax rates is to be preferred to any increases in taxes 
either now or in the future, so as to address the projected fiscal deficit. Other approaches are preferred such as a commitment to continued economic growth (to generate additional revenues), combined with encouraging private sector funding and continued restraint in government expenditures. As Thompson (2003, 2004) has pointed out, that a more fundamental question has been avoided: what if anything is problematic about future generations facing a larger tax burden or a greater level of public debt? As Thompson (2003:3) argued, '[to] merely assert that intergenerational fiscal inequity is something to be avoided', is to assume a position that requires argument, and it will require an exercise that goes to questions of justice.

The fact that the intergenerational reports fail to explicitly defend the assumption that intergenerational inequity is a problem, does not mean that the problem of intergenerational equity is thereby avoided. The assumption that intergenerational inequity is a problem requires us to ask: on what basis do we understand there is a problem. If intergenerational inequity is a problem then we are required to identify the principles of justice that it breaches so that more positively governments can develop policies that promote just outcomes. Clarifying the principles of justice that are at stake in the relations between different generations will enable governments to better promote intergenerational equity.

Thompson (2003) is right to argue that certain ideas about justice are implied in the intergenerational reports. Our ideas of justice are best framed as the answers we give to the question: 'what do we owe to others?'(Scanlon 2000). As Thompson points out, the intergenerational reports rely on two ethical ideas about intergenerational fiscal equity, namely pursuing a good and sustainable quality of life, and applying a 'benefitter-pays' principle of fairness. ${ }^{5}$ In both cases as she argues, there are implicit ideas about fairness operating, but these are neither elucidated nor defended. That is, neither the goal of achieving future well-being, nor the 'benefitter-pays' principle are defended as goods in and of themselves. Thompson (2003:6) argues that any discussion of fiscal sustainability needs to dig deeper and to find 'the deeper conceptual and theoretical foundations of justice, and intergenerational justice in particular'. Without necessarily endorsing any of them Thompson says we need to consider at least three broadly defined approaches to distributive justice. Each takes a liberal framework as their starting point in addressing the question of intergenerational justice. It is generally held that only one of these positions has much to offer to the development of a theory of intergenerational justice, though as we briefly indicate, this seems not to be strongly warranted.

\section{Theories of Justice}

The first is the 'mutual advantage' conception of justice. This defines a just society as one where each person - who is assumed to be both rational and self-interested - derives maximum benefit like wealth or access to valued resources they can from voluntary cooperation, and that the result of this process is just (eg, Gauthier 1986). Given that large numbers of people, for example, gamble heavily, rely on astrology or act altruistically, the assumptions about human conduct that supports this approach do not seem to sit on a robust empirical foundation.

The second approach is the 'desert' or 'entitlement' approach to justice (eg, Nozick 1974). It offers a libertarian account of rights and justice that establishes the rightness of owning property in ways that can be unequal but is nonetheless 'just' by appealing to a set of principles. For Nozick, whether any given distribution of property or resources is just depends on how the distribution came about. If it came about in accordance with the rules of acquisition, transfer and rectification, then it is not unjust, however unequal it may be. For Nagel (1975) Nozick's argument is too thin to be credible. This is because it is neither able nor willing to acknowledge the empirical and ethical problems created by the substantive inequalities that characterise most societies.

At the least that problem is acknowledged by the third approach that seeks to justify an egalitarian approach. This is the 'fair outcomes' approach to justice exemplified by Rawls 
(1971). Rawls' famous account of justice says that a just society is one in which the relevant institutions and relations produce outcomes that its members regard as fair. It will be recalled that Rawls attempted to construct a procedural and rational model of justice based on what he called 'the original position'. This involved people making a 'fair choice' based a commitment to just treatment, while assuming 'ignorance' about the people whose lives would be affected by their decisions. The idea of the "veil of ignorance' presumed that:

... no-one knows his place in society, his class position or social status, nor does anyone know his fortune in the distribution of natural assets and abilities, his intelligence, strength, and the like. I shall even assume that the parties do not know their conceptions of the good or their special psychological propensities. The principles of justice are chosen behind a veil of ignorance (Rawls 1971:11).

As for the two key principles of justice, Rawls pointed first to 'the difference principle' that allows for inequalities in the distribution of goods when and only if those inequalities benefit 'the worst-off members of society'. The other principle is the idea that offices and positions ought to be open to everyone under conditions of equal opportunity. Rawls believed that the difference principle was a rational choice for participants in the 'original position' for one key reason. He assumed that each member of society had an equal claim on their society's goods. Natural issues like genetic talent or bodily ability should not affect this claim, so the right of any individual, before further considerations are taken into account, must be to an equal share in material wealth. Implicit in Rawls' approach was the idea that the generation one belonged to was irrelevant. As Rawls (1999:254) put it the veil of ignorance means that people:

... do not know to which generation they belong or, what becomes the same thing, the stage of civilization of their society.

As Laslett and Fishkin (1992:20) have noted, Rawls' Theory of Justice 'marked the proper initiation of obligations to future generations as a topic of salient philosophical interest'. (This may be for the simplest of reasons like the idea that parents are generally disposed to care about their children's well-being and to make sacrifices for them). Sunstein (2007:269) has extrapolated the Principle of Intergenerational Neutrality from Rawls' theory. Does this offer a useful way of thinking about intergenerational justice in ways that might be useful for policymakers?

\section{The Principle of Intergenerational Neutrality}

For an adequate discussion about intergenerational equity we need to reinstate the perspectives, interests and needs of currently living young people as well as yet-to-be born cohorts of young people. Secondly what ethical principles might we rely on to establish whether it is a good thing for future generations to be required by policy-makers today to be responsible for a larger tax burden or a greater level of public debt? As an initial step we might consider using the Principle of Intergenerational Neutrality.

As Sunstein (2007:269) explains, this principle proposes: that 'the decade of one's birth has no moral relevance any more than does one's skin color or sex' when addressing the question of justice or fairness. This principle helps us to think about equity across generations, including equity for those not yet born, in ways that do not create invidious problems. To establish why this matters we need to consider briefly the problem of inequity or unfair treatment.

The significance of inequity can be appreciated by using a real, or imagined, difference between one person or group and another to justify unequal treatment that disadvantages the person or group at whom that treatment is directed. How this works can be seen when one group of people who are equally skilled or talented or who fulfill the same roles as others, do not get the same treatment or rewards because another dominant or powerful group use a factor like age or gender to justify unequal treatment. Conversely another form of inequity can result from using a principle of treating everyone as if they are the same. Denying that some differences matter and need to be 
compensated for can create inequities. A declaration for example that all citizens should be treated equally can mean that certain differences like physical disabilities are not acknowledged which leads to those with disabilities being disadvantaged because they cannot access buildings or valued services like public transport or education.

There is also the question of when is it appropriate to decide that the relations between different groups are best described as a difference and when they are unfair. Consider the question of age cohorts. We now have a situation where older people consume more medical and hospital services. Is this a case of difference or one involving unfair or discriminatory treatment? There is a case for saying that the heavy investment of capital in health care facilities and services favoring older people does not reflect deliberate or prejudicial decisions to favor older people. Rather, it reflects the fact that the health care claims of older people are greater than those made by younger people. That is, the difference in allocation of resources reflects the fact that there is more extensive ill-health and morbidity among older people. Or consider the historical fact that a century ago the average life expectancy for men was 49 years. Today the average is say 79 years. While that difference reflects a range of social, policy based or technological changes (ie, better medical treatment, etc), would we say it is unfair? Is this a case of 'difference' that is grounded in history and not something we would describe unfair treatment?

This Principle of Intergenerational Neutrality has been widely discussed (Weiss and Brown 1991; Portney and Weyant 1999; Howarth 2005; Sunstein 2007). It proposes that the citizens of every generation be treated equally. In environmental policy, the field where this idea has been discussed most widely, it translates into the protocol idea that present generations are 'obliged to take the interests of their environmentally threatened descendents as seriously as they take their own' (Sunstein 2007:13). The Principle of Intergenerational Neutrality suggests there is a problem if people born for example in 1950, and who now make policy decisions designed for example to address environmental issues like global warming or water resources, but fail to consider those who will be born in 2030 or 2050 by treating those people as worthy of less concern by virtue of their birth date.

The Principle of Intergenerational Neutrality entails that if we take the idea of justice seriously then we need to take into account the interests of generations who have not yet been born. However the Principle of Intergenerational Neutrality shares with Rawls' larger conception of justice, the problem that it does not provide a contentful basis for determining either the facts of the case that need evaluation or the basis for adjudicating between competing claims about the goods that should be pursued - or the bad that should be avoided (Sandel 1998).

Further the principle challenges the idea that it is acceptable to treat people differentially on the basis of their age is also a weakness. On the one hand we can agree that it is unacceptable to use identity markers like gender, sexuality, or religion to discriminate against people. The use of markers like age to distribute valued resources unequally is destructive of many valued ends and goods. Significant inequities or injustices undermine political, social and ethical values like freedom, good health, and human freedom. However where there are blatant inequities which work by treating people's age, level of ability, gender, income level, sexuality, or religion to discriminate against them we may need to practice 'reverse discrimination' which works by acknowledging those identity markers and the ways that inequalities are attached to or distributed by using these markers.

Here we also see the characteristic problems attached to an excessive regard for abstract rationality, especially when it is linked to the search for a singular or monistic principle of justice. Against the preference favoring a monistic principle of justice, we do not believe we need a single principle on which to ground a view of justice. ${ }^{6}$ While this is not the place to argue this here, we argue that we live in a world where there are incommensurable and multiple ways of evaluating the elements that constitute a good life or that inform our idea of justice or fairness (Sen 2009). 
What we need is a defensible account of how we might carry out an empirical and normative assessment of the extent to which a given society either now or in the future sustains social fairness. That is we need some capacity to establish both descriptively and normatively how we can know about the way social resources and benefits are currently distributed in a given society if we are also to engage the question of intergenerational justice. If we are to do this we need to start with a conception of freedom-as-capability (Sen 2009). In effect if we are to set up the capacity to establish intergenerational justice, we need to know a lot about the extent of current intergenerational equity and link this to quite detailed exercises in intergenerational accounting. Although we cannot detail this as fully as we would like here, we argue there is value in identifying and measuring social well-being based on Sen's (2009) freedom/capabilities approach in ways that can work in a framework of generational accounting.

\section{Sen on Freedom-as-Capability}

Sen (2009) avoids the problems of Rawls abstracted account of justice by focusing on an ethic of freedom. Sen's starting point is to ask how can we evaluate aspects of a person's life or those of a community against an idea of justice? For Sen argues any assessment ought to be based on the extent to which people are free to choose and then to pursue the goods they value. To have freedom firstly is to have opportunities to pursue our objectives, namely the goods that we value. This is the 'opportunity' aspect of freedom. What Sen calls a 'comprehensive outcome' approach to freedom takes into account people's capacity to choose between various valued ends, and then to be able to pursue those ends. Secondly freedom ought to mean that we are free from unwarranted constraints imposed by others. (This is a 'process' approach to freedom). In short, Sen accepts the need to acknowledge a plurality of values, while being mindful of people's capacity to choose freely and being able to pursue the valued ends.
We need to be able to assess the extent to which people are actually capable of freely choosing and then pursuing those goods which they value. This takes into account being free to value different ends - for example, being free to choose between alternative conceptions of the goods that we want and then being able to pursue those valued ends. Hence his insistence on the capabilities people have because a comprehensive view of freedom is not interested in the culmination outcomes, but in the whole process of choosing and being able to pursue those ends. Hence too an interest in the whole of a person's life and not:

... just on some detached objects of convenience, such as incomes or commodities that a person may possess, which are often taken, especially in economic analysis to be the main criteria of human success (Sen 2009:233).

Sen emphasises that this requires us to focus on more than just the means of living and rather to attend to the actual opportunities of living. For this reason Sen (2009:253) rejects any proposal to use income or wealth as a simple or singular measure of the 'good life' or of 'progress'. Sen says that resources like income or education may be used advantageously - or not in a variety of ways because of differences in personal characteristics, people's physical environment, their social relationships and their culture. This affects their capacity to use income and other resources to avoid poverty. This framework opens up a rich new approach (already being trialed in France since 2009) to a framework of social accounting directly relevant to any government serious about developing policies that have a chance of securing both the human goods and the kinds of human relations enabling all of their citizens to flourish (Stiglitz, Sen and Fitoussi 2009).

As Stiglitz, Sen and Fitoussi (2009:12) argue, it is time to shift the emphasis away from 'measuring economic production to measuring people's well-being'. Their interest is in 'assessing whether levels of human well-being can be sustained over time' understanding that this 'depends on whether stocks of capital that are important (natural, physical, human, social) are passed on to future generations' (Stiglitz, Sen 
and Fitoussi 2009:11). What they have in mind is a capacity to identify and assess levels of well-being within a given community and how they change over time. They want to be able to assess the inequalities which mean some people face excessive disadvantage while others enjoy excessive privilege. The elements of well-being that need to be assessed include material living standards, health, education, personal activities including work, political voice and governance, social connections and friendship, the quality of the environment and the various kinds of insecurity. This approach to well-being we argue, is entirely compatible with a generational accounting framework: in effect an enlarged approach to 'measuring' well-being also opens up the opportunity to engage in intergenerational accounting.

\section{The Value of Generational Accounting}

The 'generational accounting' framework was first developed by Auerbach et al. (1991) (see also Auerbach et al. 1994; OECD 1997; Bonin 2001). ${ }^{7}$ As developed in Europe, generational accounting involves calculating the present value of net tax payments (ie, taxes paid $m i-$ nus transfers paid for example from pensions and income support schemes) and presenting this in a present value and a rest-of-life calculation for every cohort of people presently alive and/or born in the future (Raffelhuschen 1999; Gallagher 2006). ${ }^{8}$ Generational accounting calculates the 'residual' required to balance the governments' inter-temporal budget constraint. This entails adding-up all current and future generations net payments (which in Europe are typically negative) and subtracting (adding) the explicit net debt (wealth). This enables a calculation of the fiscal gap with respect to those demands on future budgets which would ensure sustainable fiscal policy. This allows for a reasonable estimate of the true government debt or wealth for the base year since it makes explicit those government liabilities not included in the standard debt statistics published by governments. (These liabilities may include entitlements to pension benefits that young people get in a pay-as-you-go sys- tem by paying their contribution to state insurance schemes). The overall true inter-temporal debt is assumed to be financed by the net tax payments of all future generations. In reality how this burden will be actually distributed is of course unknown because it will depend on unknown future policies. If possible as Raffelhuschen (1999:168) explains, this can be calculated to take account of age and gender over the remaining lifetimes of representative individuals with the help of relevant micro data. To make this exercise possible European generational accounting treats all non-age specific government (consumption) expenditures as if they are distributed uniformly over the lifecycle while government consumption is allocated equally to all generations thus reducing their net tax burden.

Generational accounting is valuable firstly because it recognises that the traditional budget accounting preoccupation with cash-flow deficits and the size of surpluses/deficits is unable to identify factors like future liabilities of tax based retirement-based income schemes and so is 'unreliable as indicators of fiscal sustainability' (Raffelhuschen 2002:75). As Raffelhuschen (2002:76) explains:

... generational accounting reports for every generation alive (or even unborn) the remaining net payments to the budget and distribute the resulting burden or surplus equally on all future generations ... it suggests that there are no free lunches that is expenditures in the future have to be paid for either by present or future generations. In short, it takes a long term view of budget making and reporting.

Secondly the value of generational accounting lies in its ability to indicate the nature of the burden passed from current to future generations based on the assumption that contemporary fiscal policy settings do not alter typically as 'set' in a given base year. It is therefore possible to provide assessments of current intergenerational ratios of expenditure and revenue effects for existing age cohorts as well as construct future hypothetical assessments of the relative ratio of burdens borne (eg, by taxation) versus benefits received (eg, income support) by existing or future age cohorts. This can 
reveal serious degrees of unfairness in the present, as well as point to possible patterns of unfairness into the future subject to the severe caveat about all such forecasts.

Finally generational accounting can illuminate the consequences of maintaining existing fiscal policies along with their social distributive effects. There is a degree of political volatility associated with the discovery that a country's current highly inequitable tax system is not fair and likely to lead to non-sustainable fiscal policies over the long haul. In Australia successive governments, and the political establishment have long refused to acknowledge the lack of equity in the total package of Australia's taxation policies, let alone question the adequacy of that system to sustain valued social functions or enable what has been called a 'fair go'. These are issues that Australian governments have not wanted to be described or discussed: generational accounting threatens to enable both.

To date the Australian government has avoided using a generational accounting framework to produce its intergenerational reports. The fact that Australia has chosen not to follow the widespread European practice of generational accounting has been a major failing of Australian intergenerational reporting. As one official associated with the Retirement and Income Modeling Unit (RIM) the unit responsible for the forecasting in the intergenerational reports has indicated, ${ }^{9}$ RIM had not had requests for generational accounting either from Treasury officials or ministers (or from the Commission of Audit (1997) which had used RIM data in 1996). Further RIM had accepted the Howard government's preference for data which related only to expenditure programs designed to reveal a 'time dynamic'. That official noted that RIM was also worried about the 'undue sensitivity of the generational accounting estimates' and the ability to give 'meaning to results'. Apparently some officials (eg, in the Department of Finance) asked about the approach, but according to this official the Howard government was happy with the policy and fiscal relevance of the program projections. While we ought to treat this explanation with respect, it does not acknowledge suffi- ciently the political consequences arising from the capacity of generational accounting to shed light on the fairness of Australia's current tax system - which a generational accounting model, for example, would generate.

\section{Conclusion}

We have argued that like Canada, the Australian approach to intergenerational equity, as distinct from intergenerational fiscal sustainability, has been largely non-existent (Foot and Venne 2005). In spite of efforts over the past few decades by a number of well-known writers (eg, Laslett and Fishkin 1992; Bengtson and Achenbaum 1993; Marmor, Smeeding and Green 1994; Thompson 2003, 2004) to address intergenerational equity, and to identify the principles of justice when considering future generational relations, these fundamental dimensions have been missing in action in Australia.

We argued that the current framing of the problem privileges certain age groups at the expense of others and runs the risk of undermining desirable forms of generational interdependence and fairness. If this agenda setting activity proceeds unchallenged, we are likely to see policies which will be inimical to any defensible conception of justice and more specifically intergenerational equity. Like Thompson (2003:2, 2004) we argued that the intergenerational reports have avoided any engagement with ethical concerns about distributive fairness and justice.

In arguing that the omission of intergenerational equity is a serious problem we examined the value of deploying the Principle of Intergenerational Neutrality which requires existing policy-makers to consider the consequences of their decisions for future generations. While addressing the challenges of the projected demographic shift, the Principle of Intergenerational Neutrality is not able to take into account equity as well as the needs, interests and perspectives of particular age cohorts. Including these considerations in descriptions of 'the problem of the demographic shift' is critical if attention is to be given to the question of justice. We also made the case for the use of generational 
accounting in Australia. Linking generational accounting and forms of practical reasoning can play a role in ensuring generational interdependence and the capacity of different generations to live together in ways that are mutually supportive, needs to be put on the agenda. Major policy agencies need to give urgent consideration to the idea of taking intergenerational accounting seriously.

\section{Endnotes}

1. The authors would like to acknowledge the value of the two anonymous referee's reports in revising this article for publication.

2. Approximately 27 countries are now carrying out regular intergenerational reporting exercises. These countries, mostly European, do so every 12 to 18 months in contrast with Australia which does its intergenerational reporting every five years (Commonwealth of Australia 2010:87).

3. In Europe, for example, the European Union (EU) relies on indicators like 'S1'(defined as 'the size of the permanent budgetary adjustment necessary for the gross consolidated debt to reach $60 \%$ of GDP in 2050 ') and 'S2' (defined as the 'size of the permanent budgetary adjustment necessary to fulfill the inter-temporal budget constraint') (European Commission 2007). In each case these definitions rest on any number of assumptions when forecasts are made, for example, that growth and interest rates stay constant over time or that such postulates as 'the law of motion of the public debt ratio' hold true.

4. This problem is not necessarily to be confused with the 'discovery' of a 'sovereign debt crisis' in Europe during 2010 with claims that government budget deficits as a share of relevant GDP especially in Greece (13.6\%), Ireland (14.3\%), the United Kingdom (12.6\%), Spain $(11.2 \%)$ and Belgium (9.4\%) were at politically unacceptable levels. Another dimension of this problem was the 'discovery' also made that some EU member states had very high levels of public sector debt (to GDP) chiefly Greece, Italy and Belgium with Payment Ser- vices Directive (PSD) to GDP ratios in excess of $100 \%$ (eg, Erlanger 2010).

5. This is the principle that people securing a present benefit ought to pay for it because it is unjust and unfair to expect the next generation to have to pay (eg, by higher taxation rates) for the aged care, health care, and pharmaceutical subsidies of the present generation.

6. We note this principle runs through philosophy from Bentham and Kant to Rawls (1971) to Nozick (1974).

7. A standard approach to intergenerational accounting involves calculating the present value of total net tax payments to the government over the remaining lifetime of a cohort born in a specific year (where net tax payments are defined as taxes paid minus transfers received). This present value of net tax payments is labeled the generational account. The intergenerational distribution of the net tax burden is analysed by comparing the generational accounts of different cohorts of the population. Most typically this is done by comparing the generational base account of a newborn in the base year with future generations ie, those born after the base year - and most typically just one year after the base year.

8. The standard approach to generational accounting can be represented in a more formal way thus:

PVGt $=$ NWGt + PVLt + PVFt.

where

PVGt $=$ Present value of prospective purchases of goods and services

NWGt $=$ Net wealth of the government PVLt $=$ Present value of future aggregate net tax payments by generations living at time $t$ PVFt $=$ Present value of future aggregate tax payments by future generations born after time t (Gallagher 2006).

9. Email conversation, 4 May 2010.

\section{References}

Ablett, J. 1996. 'Intergenerational Accounting-An Australian Perspective.' Review of Income and Wealth 42(1):91-105. 
Ablett, J. 1998. 'Intergenerational Redistribution and Fiscal Policy.' Australian Economic Review 31(1):73-79.

Auerbach, H., J. Gokhale and L. Kotlikoff. 1991. 'Generational Accounts: A Meaningful Alternative to Deficit Accounting.' In Tax Policy and the Economy, ed. D. Bradford. Volume 5. Cambridge: MIT Press.

Auerbach, H., J. Gokhale and L. Kotlikoff. 1994. 'Intergenerational Accounting: A Meaningful Way to Evaluate Fiscal Policy.' Journal of Economic Perspectives 8(1):73-94.

Auerbach, A., L. Kotlikoff, R. Hagemans and G. Nicoletti. 2004. The Economic Dynamics of an Ageing Population: The Case of Four OECD Countries. Paris: OECD.

Bacchi, C. 2009. Analysing Policy: What's the Problem Represented to be? French's Forest: Pearson Education.

Ballassone F., J. Cunha, G. Langenus, B. Manzke, J. Pavopt, D. Prammer and P. Tommasinoa. 2009. Fiscal Sustainability and Policy Implications for the Euro Area. Working Paper Series No. 994. Frankfort: European Central Bank.

Bengtson, V.L. and W.A. Achenbaum, eds. 1993. The Changing Contract Across Generation. New York: A. de Gruyter.

Bessant, J. 2008. 'Age and Equity: A Case for an Intergenerational Charter.' Journal of Australian Studies 32(3):361-373.

Bonin, H. 2001. Intergenerational Accounting: Theory and Application. New York: Springer.

Commonwealth of Australia. 2002. Intergenerational Report 2002-03. 2002-03 Budget Paper No. 5. Canberra: Commonwealth of Australia.

Commonwealth of Australia. 2007. Intergenerational Report 2007. Canberra: Commonwealth of Australia.

Commonwealth of Australia. 2010. Australia to 2050: Future Challenges. Canberra: Commonwealth of Australia.

Coombs, G. and B. Dollery. 2002. 'An Analysis of the Debate on Intergenerational Equity and Fiscal Sustainability in Australia.' The Australian Journal of Social Issues 37(4):363-381.

Coombs, G. and B. Dollery. 2004a. 'Intergenerational Fiscal Balance in Australia: Should we use Fiscal Sustainability or Intergenerational Equity?' Economic Papers 23(3):286-299.

Coombs, G. and B. Dollery. 2004b. 'The Ageing of Australia: Fiscal Sustainability, Intergenerational Equity and Inter-Temporal Fiscal Balance.' Australian Journal of Social Issues 39(4):459470.
Doughney, J. and J. King. 2006. 'Rhetoric and Reality: Neo-Liberal Ideology and Ageing in Australia, 2003-2050.' Journal of Australian Political Economy 58(2):23-43.

Erlanger, S. 2010. 'Europe Looks at the IMF with Unease as Greece Struggles.' The New York Times 24 March.

Foot, D. and R. Venne. 2005. 'Awakening to the Intergenerational Equity Debate in Canada.' Journal of Canadian Studies 39(1):5-21.

Galbraith, J.K. 1975. Money: Whence it Came, Where it Went. London: Andre Deutsch.

Gallagher, P. 2006. Australian Government Research on Ageing: Potential Impacts and Policy Responses. Canberra: ANU.

Gauthier, D. 1986. Morals by Agreement. Oxford: Oxford University Press.

Gee, E. and G. Gutman. 2000. 'Population and Politics.' In The Overselling of Population Aging, eds E. Gee and G. Gutman. Toronto: Oxford University Press.

Giddens, A. 1990. The Consequences of Modernity. Cambridge: Polity Press.

Gokhale, J. 2009. Measuring the Unfunded Obligations of European Countries. Policy Report No. 319. January. Washington: National Center for Policy Analysis.

Harvey, D. 2005. A Brief History of Neo-Liberalism. Oxford: Oxford University Press.

Hauner, D., D. Leigh and M. Skaarup. 2007. Ensuring Fiscal Sustainability in G-7 Countries. IMF Working Paper WP/07/187. Washington: International Monetary Fund.

Heller, P., R. Hemming and P. Kohnert. 1986. Aging and Social Expenditures in the Major Industrialized Countries 1980-2025. IMF Occasional Paper No. 47. Washington: International Monetary Fund.

Howarth, R. 2005. 'Against High Discount Rates.' In Perspectives on Climate Change: Science, Economics, Politics, Ethics, eds W. Sinnot-Armstrong and R. Howarth. Oxford: Elsevier JAI.

Judt, T. 2010. 'Ill Fares the Land.' New York Review of Books 29 April:17.

Kinnear, P. 2001. Population Ageing: Crisis or Transition: Discussion Paper No. 45. Canberra: The Australia Institute.

Larch, M. and J. Noguei-Martins, eds. 2006. Fiscal Indicators: Proceedings from the Directorate General for Economic and Financial Affairs Workshop, Brussels September 22, 2006. Brussels: EC Directorate General for Economic and Financial Affairs. 
Laslett, P. and J. Fishkin, eds. 1992. Justice Between Age Groups and Generations. New Haven: Yale University Press.

Leibfritz, W., D. Roseveare, D. Fore and E. Wurzel. 1995. Aging Populations, Pensions System and Government Budgets: How do They Affect Savings? OECD Working Paper No. 156. Paris: OECD.

Macfarlane, I. 2003. 'Economic Opportunities and Risks over the Coming Decades.' Reserve Bank of Australia Bulletin December:13-19.

Marmor, T., T. Smeeding and V. Green, eds. 1994. Economic Security and Intergenerational Justice: A Look at North America. Washington: Urban Institute Press.

Mayo, E. 1949. Hawthorne and the Western Electric Company: The Problems of an Industrial Civilization. London: Routledge.

Merton, R.K. 1948. 'The Self Fulfilling Prophecy.' Antioch Review 8(2):193-210.

Miller, M. and I. Siggins. 2003. 'A Framework for Intergenerational Planning.' Foresight 5(6):1825.

Nagel, T. 1975. 'Libertarianism without Foundations.' Yale Law Journal 85(1):136-151.

Nozick, R. 1974. Anarchy, State, Utopia. New York: Basic Books.

OECD [Organisation for Economic Cooperation and Development]. 1997. Ageing in OECD Countries - A Critical Policy Challenge. Social Policy Studies No. 20. Paris: OECD.

Page, E. 2008. 'Three Problems of Intergenerational Justice.' Intergenerational Justice Review 1: 9-13.

Partridge, E. 2008. 'Just Provision for the Future.' Intergenerational Justice Review 1:4-8.

Parfit, D. 1984. Persons and Reasons. Oxford: Oxford University Press.

Popper, K. 1959. 'Prediction and Prophecy in the Social Science.' In Theories of History, ed. P. Gardiner. New York: Free Press.

Portney, P. and R. Weyant, eds. 1999. Discounting and Intergenerational Equity. Washington: Resources for the Future.

Prasad, M. 2006. The Politics of Neo Liberalism: The Rise of Neo Liberal Economic Policies in Britain, Germany and the United States. Chicago: University of Chicago Press.

Rafelhuschen B. 1999. 'Generational Accounting in Europe.' American Economic Review 89(2):167170.

Raffelhuschen B. 2002. 'Generational AccountingQuo Vadis?' Nordic Journal of Political Economy 28:75-89.
Rawls, J. 1971[1999]. A Theory of Justice. Revised edition. Cambridge: Harvard University Press.

Ricoeur, P. 2000. The Just. Chicago: Chicago University Press.

Robinson. J. and D. Watts-Roy. 1999. 'Framing the Generational Equity Debate.' In The Generational Equity Debate, eds J. Robinson, D. WattsRoy and E. Kingson. New York: Columbia University Press.

Sandel, M. 1998. Liberalism and the Limits of Justice. Cambridge: Harvard University Press.

Scanlon, T.M. 2000. What Do We Owe to Each Other? Cambridge: Bellknap Press.

Schon, D. 1984. The Reflective Practitioner. New York: Basic Books.

Sen, A. 2002. Freedom and Rationality. Cambridge: Harvard University Press.

Sen, A. 2009. The Idea of Justice. Cambridge: Harvard University Press.

Solum, L. 2001. 'To our Children's Children's Children: The Problems of Intergenerational Ethics.' Loyola of Los Angeles Law Review 35(1): 163-192.

Soros, G. 2008. The New Paradigm for Financial Markets. New York: Public Affairs.

Stiglitz, J., A. Sen and J.-F. Fitoussi. 2009. Report by the Commission on the Measurement of Economic Performance and Social Progress. URL: <http://www.stiglitz-senfitoussi.fr/documents/rapport_anglais.pdf $>$.

Sunstein, C. 2007. Worst Case Scenarios. Cambridge: Harvard University Press.

Tapper, A. 2002. The Intergenerational Report is not About Intergenerational Equity, but about Fiscal Sustainability. URL: <http://www. onlineopinion.com.au/view.asp?article $=1875>$. Consulted 2 February 2010.

Thompson, J. 2003. Intergenerational Equity: Issues of Principle in the Allocation of Social Resources Between this Generation and the Next. Parliamentary Library Research Paper No. 7. Canberra: Parliament of Australia.

Thompson, J. 2004. 'Intergenerational Equity in an Ageing Society.' Agenda 11(4):83-96.

Thompson, J. 2009. Intergenerational Justice: Rights and Responsibilities in an Intergenerational Polity. London: Routledge.

Tremmel, J. 2009. A Theory of Intergenerational Justice. London: Earthscan.

Weiss, E. and W. Brown. 1991. 'Intergenerational Equity: A Legal Framework for Global Environmental Change.' In Environmental Change and International Law, ed. E. Brown Weiss. Tokyo: United Nations University Press. 